HARMONY HARMONY 6(1)(2021)

\title{
PERUNDUNGAN PADA REMAJA DI MASA PANDEMI COVID-19
}

\author{
Lia Fitriyani ${ }^{\bowtie}$, Dadi Mulyadi Nugraha, Supriyono.
}

Indonesian Education University

\begin{tabular}{l} 
Info Artikel \\
\hline Sejarah Artikel: \\
Disubmit: April \\
2021 \\
Direvisi: Mei \\
2021 \\
Diterima: Mei \\
2021
\end{tabular}

Keywords: Bullying; Pancasila Values; Pandemic. Adolescents;

\begin{abstract}
Abstrak
Masa pandemi membuat kegiatan dilakukan dari rumah, begitupun dengan kegiatan sekolah yang mengharuskan para siswa belajar dirumah. W alaupun begitu tidak menutup kemungkinan terjadinya perundungan pada remaja di masa pandemi. Penelitian ini bertujuan untuk mengetahui pengaruh nilai-nilai Pancasila dalam mencegah terjadinya perundungan pada remaja di masa pandemi covid-19. Penelitian ini menggunakan metode kuantitatif dan analisis deskriptif. Untuk memperoleh data, dilakukan dengan menyebarkan kuesioner yang diisi oleh 42 orang. Hasil temuan yang diperoleh, 83,3\% responden menyatakan bahwa nilai-nilai Pancasila berpengaruh terhadap perkembangan remaja dan sisanya menyatakan "mungkin". Temuan lainnya, 95,2\% responden menyatakan perundungan di masa pandemi akibat kurangnya pemahaman nilai-nilai Pancasila dan 4,8\% menyatakan "tidak". Lalu, sebanyak $73,8 \%$ responden menyatakan adanya pandemi yang berakibat sekolaah dilakukan jarak jauh menjadi salah satu faktor terjadinya perundungan di masa pandemi dan $26,2 \%$ menyatakan "tidak". Kemudian, 95,2\% responden menyatakan peran orang tua dan guru sangat penting di masa pandemi. Maka dari itu, pengaruh nilai-nilai Pancasila untuk mencegah terjadinya perundungan di masa pandemi ini sangatlah penting serta harus dijadikan landasan remaja dalam bertingkah laku agar tidak terjadi perilaku menyimpang dan merugikan, terlebih di masa pandemi yang merupakan situasi baru.
\end{abstract}

Abstract
During the pandemic, activities are carried out from home, as well as school activities that require
students to study at home. Even so, it doesn't rule out bullying in adolescents during a pandemic.
This study aims to determine the effect of Pancasila values in preventing bullying in adolescents
during the covid-19 pandemic. This research uses quantitative methods and descriptive analysis.
To obtain data, this was done by distributing questionnaires filled out by 42 respondents. The
findings obtained, 83,3\% of respondents stated that the values of pancasila affect the development
of adolescents and the rest stated "maybe". Otherfindings, 95,2\% respondents stated that bullying
during the pandemic was due to a lack ofunderstanding ofthe values of Pancasila and $4,8 \%$ stated
"no". Then as many as 73,8\% of respondents stated that the exixtence of a pandemic which
resulted in schools being conducted remotely was a factor in the occurence of bullying during the
pandemic period and 26,2\% said "no". Then, 95,2\% of respondents stated that the role of parents
and teachers is very important during the pandemic. Therefore, the influence of Pancasila values
to prevent bullying this pandemic is very important and must be used as a basis for adolescents in
their behavior so that deviant and detrimental behavior doesn't occur, especially during the
pandemic, which is a new situation.

(C) 2021 Universitas Negeri Semarang

Alamat korespondensi:

ISSN 2252-7133

Program Studi Pendidikan Bahasa dan Sastra Indonesia FPBS UPI

Bandung, Jawa Barat, Indonesia

E-ISSN 2548-4648

E-mail: liafitriyani@upi.edu 


\section{PENDAHULUAN}

Pandemi covid-19 yang terjadi di hampir seluruh dunia membawa dampak besar terhadap perubahan keberlangsungan hidup manusia sekarang ini. Selain itu, segala aktivitas yang dilakukan dibatasi dan dilakukan dari rumah mulai dari bekerja, belajar, dan beribadah. Pembelajaran jarak jauh tentunya adalah hal yang baru bagi sebagian besar pelajar, dengan memanfaatkan gawai, laptop, dan internet sudah bisa menjadi modal dasar untuk terciptanya kegiatan belajar mengajar. Adanya peraturan pemerintah untuk menghindari kerumunan dan tetap di rumah saja, tentunya membuat waktu di rumah saja menjadi lebih banyak. Untuk mengisi waktu di rumah saja banyak hal yang bisa dilakukan, mulai dari mencoba dan belajar hal baru, mengembangkan hobi, bermain media sosial yang sedang hits, dan masih banyak lagi. Namun, terkadang timbul rasa bosan dalam beraktivitas yang hanya dilakukan di rumah saja. Bagi remaja yang mengalami kebosanan akibat di rumah saja terkadang melampiaskan kebosanannya dengan cara yang salah dan dapat merugikan dirinya maupun orang lain. Situasi pandemi ini memang sebuah kondisi yang tidak biasa bagi semua orang terutama remaja di mana masa remaja adalah masa pencarian jati diri, dengan adanya pandemi sangat berpengaruh terhadap perkembangan remaja dalam mencari jati dirinya. Pengaruh nilai-nilai Pancasila terhadap perkembangan remaja sangat penting dengan menjadikan nilainilai Pancasila sebagai landasan dalam bertingkah laku agar dalam pencarian jati dirinya tidak menyimpang dan tidak salah arah. Pancasila memiliki kedudukan yang strategis dan perlu dipertahankan dengan mengidupkan kembali dan mengaktualisasikannya pada kehidupan (Kristiono, 2017). Nilai-nilai Pancasila bagi remaja di masa pandemi ini perlu ada dalam diri setiap remaja guna menjadi pengontrol diri terlebih di situasi pandemi.

Pendidikan kewarganegaraan yang diajarkan pada remaja di dalamnya terdapat pembahasan mengenai Pancasila, hal itu berfungsi untuk mengembangkan karakter remaja sebagai warga negara yang memilikijiwa yang sesuai dengan nilai Pancasila (Sulfemi, 2019). Dalam sila pertama, terdapat nilai-nilai Ketuhanan yang menjadi landasan untuk menjadi manusia yang berketuhanan dan beragama serta hidup bertoleransi antara sesama walaupun berbeda agama. Dalam sila kedua, terdapat nilai-nilai keadilan dan kemanusiaan yang harus ada dalam diri setiap warga negara Indonesia agar saling menghargai antar sesama dan bersikap adil tanpa membedakan suku, agama, ras, status, kedudukan, ataupun gender. Nilai Pancasila dalam sila ketiga yakni nilai persatuan, remaja sebagai warga negara Indonesia harus menjaga persatuan dan kesatuan bangsa dimulai dari hal yang kecil terlebih dahulu. Remaja sebagai generasi penerus bangsa sangat diperlukan nilai persatuan dan kesatuan agar di masa mendatang kelak bangsa Indonesia tetap bersatu dan warga negaranya memiliki rasa persatuan dan kesatuan. Dalam sila keempat, terdapat nilai kerakyatan, musyawarah dan bijaksana. Nilai dalam sila keempat ini dapat menjadi landasan dalam berperilaku di lingkungan masyarakat atau sosial, contohnya ketika remaja berinteraksi dengan teman sebayanya dan sedang membahas suatu permasalahan maka perlu adanya musyawarah untuk mencari keputusan dalam memecahkan masalah secara bijaksana. Lalu, nilai Pancasila dalam sila kelima yakni nilai keadilan, seorang remaja harus bersikap adil terhadap segala sesuatu dan kepada siapapun tidak pandang bulu sebab setiap warga negara berhak untuk mendapat keadilan dan juga wajib bersikap adil.

Nilai-nilai Pancasila yang sudah dijelaskan di atas menunjukkan bagaimana pentingnya nilai-nilai Pancasila dalam diri remaja sehingga dapat menjadi pedoman. Namun, adanya pandemi membuat pembelajaran dilakukan jarak jauh sehingga dapat memengaruhi pembelajaran mengenai nilai-nilai Pancasila karena dalam mengimplementasikan nilai-nilai Pancasila di 
masa pandemi sedikit berbeda karena dilakukan dari rumah. Dalam implementasinya pun perlu bimbingan dari orang tua dan guru. Penggunaan gawai dan internet guna melakukan pembelajaran jarak jauh yang tidak dibarengi dengan pengawasan orang tua maupun guru dapat menimbulkan permasalahan. Ini lah salah satu faktor awal terjadinya tindak perundungan di masa pandemi, perundungan dalam hal ini berupa cyberbullying. Selain dalam bentuk itu, perundungan di masa pandemi juga bisa berupa fisik maupun nonfisik karena dalam tindak perundungan ada berbagai faktor yang melatarbelakangi terjadinya perundungan itu sendiri sehingga muncul tindakan perundungan yang berbagai jenisnya tergantung faktor yang melatarbelakangi pelaku perundungan. Walaupun terjadi pandemi, tidak membuat tindakan perundungan menurun melainkan terus meningkat selama pandemi terjadi. Ini menjadi bukti lemahnya nilai-nilai Pancasila sebab ketidakmampuan mengontrol diri sehingga terjadinya perundungan.

Pada dasarnya tindakan perundungan di masa pandemi ini merupakan sebuah contoh nyata lemahnya nilai-nilai Pancasila di kalangan remaja dan memiliki dampak yang sangat buruk bagi korban tentunya. Tidak hanya korban saja yang perlu mendapat perhatian dan penanganan, pelaku perundungan pun perlu mendapat perhatian, bimbingan, serta penanganan agar kedepannya tidak menjadi pelaku perundungan lagi. Kasus perundungan ini merupakan hal yang sangat serius karena menyangkut generasi penerus bangsa, jika generasi penerus bangsa sudah rusak maka hancur bangsa tersebut. Remaja sebagai generasi penerus yang ditempatkan sebagai pemimpin masa depan perlu ditanamkan nilai-nilai Pancasila guna menjadi budaya yang khas suatu bangsa (Kristiono et al., 2019). Oleh karena itu, pentingnya nilai-nilai Pancasila ini bukan hanya sebagai pedoman hidup melainkan juga sebagai aturan dalam berperilaku di lingkungan masyarakat.
Dari latar belakang yang telah dipaparkan di atas, maka dapat dirumuskan beberapa masalah, yakni apa pengaruh nilainilai Pancasila terhadap perkembangan remaja? bagaimana pengaruh nilai-nilai Pancasila terhadap terjadinya perundungan remaja di masa pandemi? apa yang menjadi faktor terjadinya perundungan di masa pandemi? dan bagaimana mengatasi perundungan pada remaja di masa pandemi ini?

\section{METODE}

Dalam penelitian ini, metode yang digunakan adalah metode kuantitatif. Metode kuantitatif adalah metode yang digunakan untuk menemukan pengetahuan secara sistematis dengan data yang berupa angka sebagai sampel untuk menganalisis sesuatu yang ingin diketahui. Penelitian ini dimulai dengan menyebarkan kuesioner secara online yang berisi pertanyaan-pertanyaan yang akan dijawab oleh responden. Kuesioner yang dibagikan diisi oleh responden yang berjumlah 42 orang dengan berbagai latar belakang yang berbeda dan usia yang berbeda. Setelah kuesioner dibagikan, akan diperoleh hasil data berupa diagram lingkaran dan juga pendapat-pendapat dari para responden. Data yang digunakan berupa data primer yang diperoleh langsung dari responden yang telah mengisi kuesioner. Data yang sudah diperoleh akan disajikan dalam bentuk tabel, sedangkan data yang berupa pendapat-pendapat responden dianalisis secara deskriptif. Analisis deskriptif digunakan untuk mendeskripsikan dan memberi gambaran terhadap hasil penelitian berupa data dalam tabel yang telah diperoleh. Selain data yang berupa angka, digunakan juga berbagai macam sumber-sumber berupa artikel dan jurnal untuk memperkuat data yang telah dikumpulkan.

\section{PEMB AHASAN}

Data yang diperoleh dalam penelitian ini didapat dengan membagikan kuesioner kepada responden yang berjumlah 42 . Kuesioner yang dibagikan berisi pertanyaan yang berkaitan 
dengan pengaruh nilai-nilai Pancasila terhadap perundungan di masa pandemi covid-19. Hasil penelitian dapat dilihat pada tabel 1 .

Tabel 1. Nilai-nilai Pancasila berpengaruh terhadap perkembangan remaja

\begin{tabular}{|l|l|l|}
\hline \multicolumn{1}{|c|}{$\begin{array}{c}\text { Jawaban } \\
\text { Responden }\end{array}$} & $\begin{array}{c}\text { Jumlah } \\
\text { Responden }\end{array}$ & $\begin{array}{c}\text { Pesentas } \\
\text { e }\end{array}$ \\
\hline Ya & 35 & $83,3 \%$ \\
\hline Mungkin & 7 & $16,7 \%$ \\
\hline Tidak & - & - \\
\hline
\end{tabular}

Sumber: penelitian 2021.

Berdasarkan tabel 1 yang didapat dari hasil penelitian yang dilakukan, menunjukkan bahwa responden menyatakan bahwa nilai-nilai Pancasila memengaruhi perkembangan remaja apalagi di masa pandemi sekarang ini yang merupakan kondisi yang baru bagi remaja. Dengan adanya nilai-nilai Pancasila dapat dijadikan dasar dalam bertindak, membentuk karakter remaja, dan sebagai bekal bagi generasi penerus bangsa sebab nilai-nilai Pancasila dapat membentuk bagaimana menjadi warga negara yang baik.

Tabel 2. Perundungan di tengah pandemi akibat kurangnya pemahaman nilai-nilai Pancasila

\begin{tabular}{|l|l|l|}
\hline $\begin{array}{c}\text { Jawaban } \\
\text { Responden }\end{array}$ & $\begin{array}{c}\text { Jumlah } \\
\text { Responden }\end{array}$ & $\begin{array}{c}\text { Persenta } \\
\text { se }\end{array}$ \\
\hline Ya & 40 & $95,2 \%$ \\
\hline Tidak & 2 & $4,8 \%$ \\
\hline
\end{tabular}

Sumber: penelitian 2021.

Tabel 2 menunjukkan di tengah pandemi covid-19 ini, pemahaman nilai-nilai Pancasila di kalangan remaja mengalami kemerosotan sehingga terjadi perundungan. Ini disebabkan oleh adanya pembelajaran jarak jauh yang kurang efektif membuat remaja cenderung hanya mengetahui nilai-nilai Pancasila tanpa memahami dan mengamalkannya dalam berperilaku.

Tabel 3. Pembelajaran jarak jauh menjadi faktor terjadi perundungan

\begin{tabular}{|l|l|c|}
\hline $\begin{array}{c}\text { Jawaban } \\
\text { Responden }\end{array}$ & $\begin{array}{c}\text { Jumlah } \\
\text { Responden }\end{array}$ & $\begin{array}{c}\text { Persenta } \\
\text { se }\end{array}$ \\
\hline Ya & 31 & $73,8 \%$ \\
\hline Tidak & 11 & $26,2 \%$ \\
\hline
\end{tabular}

Sumber: penelitian 2021.

Hasil penelitian yang terdapat dalam tabel 3, menyatakan bahwa pembelajaran jarak jauh bisa menjadi faktor terjadinya perundungan pada remaja di masa pandemi. Namun, ada yang menyatakan bahwa entah itu pada saat pandemi atau tidak perundungan kerap terjadi pada remaja. Hanya saja saat pandemi sekarang, perundungan lebih banyak terjadi karena meningkatnya penggunaan internet yang tidak dibarengi dengan pemahaman nilai-nilai Pancasila.

Tabel 4. Pentingnya peran orang tua dan guru di masa pandemi

\begin{tabular}{|l|c|c|}
\hline $\begin{array}{c}\text { Jawaban } \\
\text { Responden }\end{array}$ & $\begin{array}{c}\text { Jumlah } \\
\text { Responden }\end{array}$ & $\begin{array}{c}\text { Persenta } \\
\text { se }\end{array}$ \\
\hline Ya & 40 & $95,2 \%$ \\
\hline Mungkin & 2 & $4,8 \%$ \\
\hline Tidak & - & - \\
\hline
\end{tabular}

Sumber: penelitian 2021.

Responden menyatakan peran orang tua dan guru di tengah pandemi ini sangat dibutuhkan terkait masalah perundungan pada remaja di masa pandemi bisa dengan memberikan pemahaman di lingkungan keluarga dan juga guru memberikan edukasi terkait pengamalan nilai-nilai Pancasila saat pembelajaran daring yang tentunya menggunakan metode yang efektif dan menarik.

Adanya nilai-nilai Pancasila berpengaruh pada perkembangan remaja terlebih di masa pandemi ini. Penggunaan gawai saat pembelajaran jarak jauh yang tidak dibarengi dengan pengawasan dari orang tua dan guru, membuat meningkatnya perundungan di masa pandemi covid-19. Pengaruh nilai-nilai Pancasila sangat besar terhadap terjadinya perundungan di masa pandemi ini, nilai-nilai Pancasila menjadi pegangan dan pedoman dasar dalam hidup terlebih di masa pandemi yang serba dibatasi. Berdasarkan penelitian yang dilakukan oleh Nurma Indana Zulfa dan Ayip M.R pada 2018, semakin tinggi pemahaman nilai-nilai Pancasila pada remaja maka semakin tinggi juga pengamalan nilai-nilai Pancasila dalam kehidupan (Indana Zulfa, 2018). Selain itu, dalam penelitiannya juga mengatakan pembelajaran mengenai Pendidikan Pancasila dan Kewarganegaraan pada remaja lebih menekankan pada nilai-nilai Pancasila yakni sila keempat dan kelima (Indana Zulfa, 2018). Dengan menanamkan nilai-nilai Pancasila pada 
remaja dapat menjadikan remaja berjiwa demokratis dan paham mengenai keadilan dan kemakmuran dalam hubungan sosial di lingkungan pertemanannya sehingga tidak terjadi perilaku menyimpang seperti perundungan. Pandangan masyarakat mengenai masalah yang terjadi pada remaja seperti tawuran, perundungan, dan lainnya disebabkan minimnya pengamalan dan pemahaman dalam diri di kehidupan sehari-harinya (Hastangka \& Prasetyo, 2019).

Perundungan di masa pandemi ini banyak bentuknya tidak hanya dalam bentuk verbal ataupun fisik, tetapi bisa juga dalam bentuk perundungan dalam jaringan atau biasa disebut cyberbullying. Menurut Coloroso (2007), perundungan bisa terjadi dalam 4 jenis yaitu perundungan fisik, perundungan verbal, perundungan relasional, dan perundungan daring (dalam ZAKIYAH et al., 2017), seperti terjadi di masa pandemi ini. Namun, yang paling banyak terjadi adalah perundungan dalam jaringan karena remaja termasuk yang paling banyak menggunakan internet di masa pandemi apalagi sekarang pembelajaran dilakukan jarak jauh sehingga resiko terjadinya perundungan sangat besar.perundungan yang terjadi di masa pandemi bisa dalam bentuk, melontarkan katakata yang tidak pantas pada korban, video atau video korban yang memalukan lalu disebar di media sosial, dan memberikan pesan-pesan ancaman yang mengintimidasi secara berulang.

Willard (2006), perundungan dalam jaringan memiliki tujuh bentuk (Rastati, 2016). Pertama pertengkaran daring dengan melontarkan kata-kata tidak pantas yang bisa terjadi di media sosial. Lalu yang kedua, perundungan dalam bentuk pelecehan berupa melecehkan seseorang berulangkali dengan katakata yang tidak senonoh. Kemudian, yang ketiga menyebarkan berita bohong dengan menuliskan dan membagikan komentar yang bohong dan rumor mengenai seseorang yang bertujuan merusak citra dan reputasinya. Selanjutnya, yang keempat bisa dengan membuat akun palsu yang berisi unggahan-unggahan mengenai seseorang yang menjadi korban perundungan agar orang tersebut memiliki citra yang buruk. Lalu, yang kelima yaitu melakukan tipu daya dengan memperdaya seseorang agar melakukan tindakan yang memalukan tentang dirinya sendiri lalu disebarkan melalui media sosial atau juga memeras korban dengan memberikan ancaman. Kemudian, yang keenam yakni perundungan yang dilakukan dengan pengucilan dalam kelompok daring yang dilakukan secara sengaja. Lalu yang terakhir perundungan dalam bentuk menguntit secara daring dengan mengirimkan ancaman dalam bentuk pesan yang mengintimidasi dan menimbulkan ketakutan dan rasa was-was tentang keselamatannya. Berdasarkan bentuk perundungan yang dikemukakan oleh Willard, jenis-jenis perundungan di atas banyak terjadi pada remaja di masa pandemi ini dan cenderung meningkat.

Menurut hasil penelitian yang dilakukan, responden menyatakan bahwa perundungan yang terjadi di masa pandemi dikarenakan kurangnya pemahaman nilai-nilai Pancasila khusunya sila kedua dan ketiga. Nilai Pancasila pada sila kedua yakni harus bersikap adil, bersikap kemanusiaan terhadap orang lain dan memilki perilaku yang baik. Dengan terjadinya perundungan ini, remaja masih sangat rendah pemahamannya mengenai nilai-nilai Pancasila sehingga tidak bisa mengamalkannya dalam kehidupan sehari-hari. Nilai-nilai Pancasila pada remaja sangat penting untuk dijadikan landasan dalam bertingka laku agar tidak terjadi tindakan perundungan. Adanya pendidikan kewarganegaraan yang di dalamnya juga memuat nilai-nilai Pancasila dalam kehidupan perlu diikuti dalam pembelajaran di sekolah agar para remaja kelak dapat mengimplementasikannya dan menjadi pribadi yang baik. Dengan begitu, generasi penerus bangsa menjadi generasi yang berpegang teguh pada nilai-nilai Pancasila dalam berperilaku.

Namun, adanya pandemi membuat pembelajaran di lakukan secara daring yang mana memiliki banyak rintangan karena hal ini 
rmerupakan hal yang baru dilakukan dan tidak semua remaja bisa mengikutinya dengan baik. Hal itu juga dapat berdampak pada pembelajaran mengenai pendidikan kewarganegaraan yang disampaikan oleh guru. Menurut responden pembelajaran daring ini sulit untuk menyerap materi sehingga pembelajaran mengenai nilai-nilai Pancasila kurang dipahami karena tidak ada interaksi langsung antara murid dan guru dan berdampak pada realisasi dari nilai- nilai pancasila itu sendiri. Jika pembelajaran langsung remaja bisa dengan mudah mengimplementasikannya atau menerapkan dalam lingkungan pertemanannya.

Pembelajaran daring ini juga dibutuhkan peran orang tua untuk mendampingi dan berperan sebagai guru di rumah dengan memberikan contoh bagaimana mengimplementasikan nilai-nilai Pancasila dalam lingkungannya walaupun di lakukan secara daring tetap berlandaskan pada nilai-nilai Pancasila dalam bersosialisasi di media sosial agar tidak terjadi tindakan perundungan. Hubungan yang baik antar anak dan orang tua sangat berdampak pada perkembangan remaja, dengan komunikasi yang baik anak akan dapat mengontrol dan mengendalikan dirinya dari perilaku tidak terpuji seperti perundungan (Malihah \& Alfiasari, 2018). Kontrol diri sangatlah penting pada remaja terlebih di masa pandemi ini yang merupakan situasi yang tidak biasa dialami remaja, hubungan pertemanan di masa pandemi yang dilakukan dalam bentuk daring memiliki perbedaan dengan hubungan pertemanan yang dilakukan secara tatap muka langsung. Hal ini sangat memungkinkan terjadinya perundungan di dunia maya karena bisa timbul kesalahpamahan mengenai suatu hal, dengan kontrol diri yang lemah remaja akan memandang hal tersebut dengan emosi yang negatif karena tidak mampu mengontrol dirinya sehingga timbul perundungan.

Faktor terjadinya perundungan di masa pandemi seperti yang sudah disebutkan di atas yakni kontrol diri yang lemah pada remaja yang menyebabkan timbulnya perundungan. Selain itu, kurangnya pemahaman tentang nilai-nilai Pancasila terlebih di masa pandemi ini pembelajaran daring sehingga guru tidak bisa mengawasi secara langsung bagaimana remaja itu bersosialisasi dengan temannya dan memastikan apakah pengamalan nilai-nilai Pancasila sudah dilakukan dalam interaksi sosialnya. Walaupun ada orang tua di rumah, belum tentu mengawasi bagaimana anaknya bergaul dan bagaimana pembelajaran daring yang diikuti anaknya agar penyampaian mengenai pemahaman nilai-nilai Pancasila dapat tersampaikan dengan baik dari gurunya dan dapat diimplementasikan dalam kehidupannya. Dengan begitu orang tua bisa memberikan contoh langsung dan menanamkan nilai-nilai Pancasila pada diri anaknya.

Masa pandemi ini juga menimbulkan kebosanan pada diri remaja yang mana sebelum pandemi bisa bertemu teman-temannya dengan mudah. Namun, saat pandemi intesitasnya di batasi atau bahkan tidak bisa bertemu langsung. Selain itu, faktor lain yang menyebabkan terjadinya perundungan adalah tingginya harga diri pada remaja. Menurut penelitian yang dilakukan Melotti dan Brighi pada 2012, remaja yang memiliki harga diri yang sedang ke tinggi dan di lingkungan pertemanannya berpandangan bahwa di antara teman-temannya memilki harga diri yang tinggi bisa berpotensi menjadi pelaku perundungan (dalam Ragasukmasuci \& Adiyanti, 2019). Hal tersebut sejalan dengan penelitian yang dilakukan Reginasari (2017), menurut hasil penelitiannya mayoritas dari partisipan penelitiannya yakni $82,6 \%$ merupakan kelompok harga diri tinggi yang cenderung berisiko menjadi pelaku perundungan pada tingkat tinggi. Perundungan pada remaja tersebut dilakukan untuk mendapat perhatian dan pengakuan dari teman sebayanya yang mendukung tindakan perundungan tersebut (dalam Ragasukmasuci \& Adiyanti, 2019).

Pengamat Pendidikan, Adjat Wiratma (2020) dalam Kompas.com, faktor yang menjadi penyebab terjadinya perundungan di masa 
pandemi ini adalah tingkat kebahagian anak yang akan berpengaruh pada penggunaan media sosial dan kebosanan. Saat kebahagian seorang remaja tidak didapat dalam kehidupannya maka ia akan mencari kebahagian lain salah satunya dengan menjadikan seseorang sebagai bahan perundungan dengan menindasnya dan hal tersebut menurutnya merupakan kebahagian tersendiri. Selain itu, saat kebosanan pada remaja melanda hal yang timbul kemudian adalah menggunakan media sosial, penggunaan media sosial tanpa pengawasan dan tidak dibarengi dengan pemahaman bermedia sosial yang baik akan dapat memicu terjadinya perundungan secara daring. Perundungan ini dipicu karena timbulnya rasa bosan lalu melakukan tindakan perudungan melalui daring hanya karena keisengan semata, padahal dampak yang ditumbulkan terhadap korban sangat besar.

Pencegahan tindak perundungan di masa pandemi khusunya perundungan daring dapat dilakukan dengan cara saat menggunakan sosial media jangan mudah menerima pertemanan dari orang yang tidak dikenal ataupun orang yang sudah terindikasi sering melakukan perundungan. Selain itu, hindari mengunggah dan mengirimkan kata-kata, video, ataupun gambar yang tidak pantas agar hal tersebut tidak dijadikan bahan perundungan. Lalu, jangan menulis semua informasi pribadi di media sosial supaya tidak menimbulkan pencurian identitas untuk pembuatan akun palsu yang digunakan untuk bahan perundungan. Kemudian, jangan mudah terpancing terhadap apapun di media sosial yang mengarah pada hal yang negatif dan mengarah pada pertengkaran. Penggunaan media sosial dengan baik dan bijak pada remaja serta adanya pengawasan orang tua mulai dari apa saja media sosial yang dimiliki anaknya berikan pemahaman bermedia sosial yang baik dan benar, berikan pemahaman apa saja yang tidak boleh dilakukan dan tidak ditiru oleh remaja tehadap apa yang dimedia sosial. Selain itu, memberikan pemahaman mengenai nilai-nilai Pancasila pada remaja, walaupun disekolah atau saat pembelajaran daring sudah diberikan tapi orang tua juga perlu memberikan pemahaman dan menanamkan nilai-nilai Pancasila pada remaja sebagai pedoman dalam bermedia sosial yang baik.

Cara menanamkan nilai-nilai Pancasila pada remaja di masa pandemi dapat dilakukan membutuhkan peran serta orang tua dan guru, walaupun pembelajaran dilakukan jarak jauh peran guru dalam hal ini sangat penting. Beberapa cara agar nilai-nilai Pancasila tetap ditanamkan pada remaja walau pembelajaran jarak jauh, pertama adalah Kemendikbud telah memasukkan nilai-nilai Pancasila pada Program Belajar dari Rumah yang ada di TVRI, maka orang tua bisa mendampingi anaknya untuk menonton sekaligus memberikan pengetahuan baru bahwa di masa pandemi ini sebagai warga negara harus tetap menjadikan nilai-nilai Pancasila sebagai pedoman berperilaku. Selain itu, orang tua berperan juga sebagai guru di rumah dengan memberikan nilai-nilai karakter yang dilakukan secara nyata di rumah, seperti melakukan sholat lima waktu, menyelesaikan tugas-tugas, mengajarkan bagaimana berpikir kritis dalam menghadapi suatu masalah, membuat jadwal untuk bermain gawai, dan saling gotong royong sesama anggota keluarga. Dengan menanamkan hal-hal tersebut akan timbul dalam diri remaja nilai-nilai Pancasila dalam bersosialisai dengan teman baik bertemu langsung maupun tatap maya, maka tindakan perundungan tidak akan terjadi pada remaja. Dengan begitu, para remaja akan siap sebagai generasi penerus bangsa mengahadapi tantangan yang menghadang di masa mendatang dengan berlandaskan nilai-nilai Pancasila sebagai pedoman dalam dalam berhubungan di masyarakat.

\section{SIMPULAN}

Setelah hasil penelitian yang dibahas di atas, dapat disimpulkan bahwa nilai-nilai Pancasila sangat berpengaruh pada perkembangan remaja terlebih di masa pandemi seperti sekarang. Adanya perundung pada remaja di masa pandemi menjadikan bukti 
bahwa nilai-nilai Pancasila di kalangan remaja mengalami kemerosotan serta rendahnya pemahaman dan pengamalan nilai-nilai Pancasila menjadi salah satu faktor penyebab terjadinya perundungan pada remaja. perundungan pada remaja yang terjadi di masa pandemi memiliki banyak jenis dan yang paling tinggi adalah perundungan dalam jaringan yang terjadi di media sosial. Maka dari itu, pembelajaran jarak jauh yang mengharuskan remaja menggunakan gawai memerlukan bimbingan dan perhatian dari orang tua dan guru agar tidak digunakan secara sembarangan dan berlebihan yang bisa menimbulkan perundungan.

Pemahaman mengenai nilai-nilai Pancasila yang didapat dari sekolah atau guru saat melakukan pembelajaran jarak jauh perlu ditingkatkan kembali dan orang tua juga harus memberikan pemahaman kembali tentang pentingnya nilai-nilai Pancasila. Faktor penyebab terjadinya perundungan di masa pandemi karena tingkat kebahagian yang rendah dan rasa bosan pada remaja dapat dihindari dengan membuat kegiatan di rumah bersama anggota keluarga ataupun kegiatan positif bersama teman melalui media daring. Dengan begitu, tidak timbul rasa bosan dan tingkat kebahagian menjadi tinggi. Pengaruh nilai-nilai Pancasila sangat besar bagi remaja, maka dari itu pemahaman dan pengamalan nilai-nilai Pancasila perlu ditanamkan dan harus ada dalam diri remaja sebagai generasi penerus bangsa yang berlandaskan nilai-nilai Pancasila.

\section{DAFTAR PUSTAKA}

Bayu Galih. (2020). Menurut Pengamat, Ini Faktor Penyebab Anak Lakukan Cyber Bullying. Diakses pada 24 April 2021, dari https://nasionalkompas.com/read/2020 /11/28/13055791/menurut-pengamatini-faktor-penvebab-anak-lakukan-cvberbullving

Hastangka, \& Prasetyo, D. (2019). Analisis Pelaksanaan Mata Kuliah Pendidikan Pancasila di Perguruan Tinggi. Jurnal
Rontal Keilmuan PKn, 5(2), 1-12.

Indana Zulfa, N. (2018). Pengaruh Nilai-Nilai Pancasila Terhadap Kemampuan Dalam Mengamalkan Sila-Sila Pancasila Siswa Di Kelas VIII SMP Negeri 3 Singojuruh Semester Ganjil. JPPKn, 3(1), 24-29. https://ejournal.unibabwi.ac.id/index.ph p/jppkn/article/view/663

Kristiono, N. (2017). Penguatan Ideologi Pancasila Di Kalangan Mahasiswa Universitas Negeri Semarang. Harmony, 2(2), 193-204. https://journal.unnes.ac.id/sju/index.ph p/harmony/article/view/20171/9563

Kristiono, N., Harto Wiratomo, G., \& Nuha Alfira, H. (2019). Implementasi NilaiNilai Pancasila Dalam Kegiatan Kepramukaan (Studi Kasus Madrasah Aliyah Al-Asror Semarang). Harmony: Jumal Pembelajaran IPS Dan PKN, 4(1), 1318.

http://journal.unnes.ac.id/sju/index.php /harmony

Malihah, Z., \& Alfiasari, A. (2018). Perilaku Cyberbullying pada Remaja dan Kaitannya dengan Kontrol Diri dan Komunikasi Orang Tua. Jumal Ilmu Keluarga Dan Konsumen, 11(2), 145-156. https://doi.org/10.24156/jikk.2018.11.2. 145

Ragasukmasuci, L. B., \& Adiyanti, M. G. (2019). Kecenderungan Remaja menjadi Pelaku Perundungan-Siber: Kontribusi Harga Diri dan Kesepian. Gadjah Mada Joumal of Psychology (GamaJoP), 5(2), 187. https://doi.org/10.22146/gamajop.4845 0

Rastati, R. (2016). Bentuk Perundungan Siber Di Media Sosial Dan Pencegahannya Bagi Korban Dan Pelaku. Jurnal Sosioteknologi, 15(2), 169-186. https://doi.org/10.5614/sostek.itbj.2016. 15.02.1

Sulfemi, W. B. (2019). Penerapan model pembelajaran discovery learning meningkatkan motivasi dan hasil belajar pendidikan kewarganegaraan. ... Pancasila Dan Kewarganegaraan. 
http://www.jurnal.stkippgritulungagung. ac.id/index.php/rontal/article/view/102

ZAKIYAH, E. Z., HUMAEDI, S., \& SANTOSO, M. B. (2017). Faktor Yang Mempengaruhi Remaja Dalam Melakukan Bullying. Prosiding Penelitian Dan Pengabdian
1

Kepada Masyarakat, 4(2), 324-330. https://doi.org/10.24198/jppm.v4i2.14352 